\title{
Vertical and horizontal communication on the Facebook pages of 2014 Brazilian presidential candidates
}

Lídia Raquel Herculano Maia*, Federal University of Paraíba, Department of Communication, Brazil

Olga Demushina, Russian Academy of National Economy and Public Administration, Public

Administration Department, Russia

Stephen D. McDowell, Florida State University, School of Communication, USA

*Corresponding author: lidiarhmaia@outlook.com

\begin{abstract}
Social networking sites can be defined as online services that allow users to create public or private profiles and, among other things, create connections, share opinions, news, and affections. In 2014, many electors in Brazil were engaged in the presidential campaign on these virtual spaces as never before. In this context, the research question guiding this study is: What are the communication strategies employed by electors and the three main presidential candidates in the online interaction processes during the 2014 Brazilian elections? To address this question, empirical research was employed using a qualitative approach to analyze comments posted in the candidates' Facebook fan pages during that electoral process. Based on the research and theory in this field, two types of communication in the virtual space were investigated: (a) vertical communication through interaction between Internet users and campaign staff; and (b) horizontal communication among electors in the comments section. We conclude that, although the comments section of the candidates' pages on Facebook is frequently used as a space both for mutual support and incivility against opponents, it is still used creatively for discussion on the candidates' government plans, the situation of the country, attempts of engagement in the electoral process and exposure to ideologically crosscutting viewpoints.
\end{abstract}

\section{Keywords}

Brazil, online interaction, political participation, presidential campaign, social media, vertical and horizontal communication

\section{Introduction}

The forms and extent of political participation in democratic elections using new electronic and social media are a core focus of research for many scholars from different countries (Bernhard, 2018; Bimber \& Davis, 2003; Erikson, 2008; Nielsen, 2011; Stier, Bleier, Lietz, \& Strohmaier, 2018; Stromer-Galley, 2000; Vitak et al., 2011). In the past decade, several election campaigns and other political events took place in many countries. These include: presidential elections in Austria and the USA; legislative elections in Spain, Australia, and Russia; the impeachment of Brazil's president and the Brexit referendum campaign in the UK in 2016; presidential elections in France and UK in 2017; and legislative elections in the Netherlands and Japan. These political events and election campaigns employed new forms of political engagement using electronic media, including some misleading campaign information, and showed the importance of interactions between different actors in the election process.

To investigate the forms and modalities of online interaction processes during an election campaign in more depth, the federal election in Brazil in 2014 was chosen for examination in this paper. This is a useful example for many reasons: First, the presidential election in Brazil had a high turn-out in 2014, which demonstrated the strong interest of the Brazilian population in greater political participation. Second, Brazil is the largest national economy, population, and territory in Latin America. Finally, from that election, "the internet 
and social networks have become instrumental in spreading information about candidates, following news and debates and tracking issues ranging from corruption to pension reform" (Arnaudo, 2017, p. 5). For this reason, the relatively young Brazilian democracy offers a critical case to examine the use of social media for political participation.

The 2014 Brazilian presidential election cycle also represented a milestone in Brazil. It was the most competitive campaign in the country and presented intense debates on electronic networks and the streets (Barifouse, 2014). Three candidates dominated the contest: Dilma Rousseff (Workers' Party - PT), Aécio Neves (Brazilian Social Democracy Party - PSDB), and Marina Silva (Brazilian Socialist Party - PSB). The first round of elections took place on October 5, 2014. In this round Rousseff received $42 \%$ of the votes, Neves $34 \%$, and Silva $21 \%$. None of the candidates obtained over $50 \%$ of the valid votes, and so the second round of voting was held on October 26, 2014. In this round, Dilma Rousseff was re-elected with $52 \%$ of the votes, against $48 \%$ of the votes for Aécio Neves. The polarization shown in this result was not over with the end of the election. After the dispute, in 2015 groups opposed to Dilma Rousseff and the Workers' Party organized the biggest street protests in Brazil's recent history and made dozens of impeachment requests. One of these requests was accepted by the Congress and Senate in 2016. Thus, Brazil reached the 2018 election even more polarized and enshrined the extreme rightwing politician, Jair Bolsonaro, as new president. Therefore, observing the interaction processes evidenced in the 2014 presidential campaign remains relevant, even after the 2018 election, considering all the developments that this fierce election provoked.

A study on the use of information and communication technologies in Brazil developed by the Brazilian Internet Steering Committee, shows that, in 2014, half (50\%) of Brazilian households had Internet access, which represents a growth of twenty-three percentage points compared to 2010 (Bra- zilian Internet Steering Committee, 2014, p. 176). In the same period (2010-2014) the number of subscribers to Brazilian Facebook grew from 6 to 89 million (Barifouse, 2014). Thus, there was a much larger proportion of the population using the leading social media platform in the 2014 elections than in previous elections.

The rapid growth of the number of Internet users stimulated the expansion of interaction processes between electors and the candidates' campaign staff, mainly on social media platforms such as Facebook. Social networking sites are defined here as online services that allow users to create public or private profiles and navigate to other user profiles (Harlow, 2013). Using social media, people can, among other things, create connections with each other and share opinions, news, and affections. In 2014, in these virtual spaces, many electors in Brazil were engaged in this campaign for three months as never before (Barifouse, 2014). Investigating the online interaction processes between electors and candidates' campaign staffs, specifically, interactions that took place in the Brazilian presidential campaign via Facebook pages, will assist in further developing models that can be used to analyze political uses of social media.

Many studies have been undertaken to understand the conduct and dynamics of political campaigns using the Internet (Bernhard, 2018; Bimber \& Davis, 2003; Segaard \& Nielsen, 2013; Stier et al., 2018; Stromer-Galley, 2000; Vitak et al., 2011). The emphasis of these studies is most often the analysis of how social media, websites, and virtual tools have been used by the politicians and campaigns in the electoral period. Differently, the contribution of our research is to focus on what the electors do in these campaigns. Thus, our main attention is focused on understanding how the electors try to contribute through social media to build a good image for the politicians they choose to support.

There is a common view that people do not use the Internet properly to become engaged in electoral campaigns or political conversations. Stromer-Galley and Wichowski (2011) comment that, in- 
stead of reasonably argued positions, we observe aggression, irrational discourses, and argumentative poverty in Internet posts. However, "although the discussion may be uncivil and ideological, people still engage in it, it still matters to people who want to engage in political discussion" (Stromer-Galley, 2000, p. 114). Thus, electors' engagement in political events matters. Their discussions about what government policies would be better for the country and their positioning as agents of discourse in the democratic process should be investigated, even if this participation is accompanied by uncivil and impolite postings.

The research question guiding this study is: What are the communication strategies employed by the participants (electors and candidate's campaign staff) in the online interaction processes during elections? We investigate the interaction processes that took place in the Facebook pages of the three main candidates in the 2014 Brazilian presidential election to explore this question. Based on the research and theory in this field, two types of communication in the virtual space were investigated: (a) vertical communication through interaction between Internet users and campaign staff; and (b) horizontal communication among electors in the comments section. Through exploratory abductive research (Dubois \& Gadde, 2002), we aim to develop an observation-based typology of vertical and horizontal social media interactions that can be applied by future research.

\section{Literature review}

According to Bourne (2010), political participation can be understood as a broad concept since it can include different forms of activities. The broadness of the concept engenders difficulties in its definition (van Deth, 2014). But, if we consider the purpose underlying political participation, it can be defined as an activity aimed at the impact on political authority.

The development of information technologies has extended opportunities for participation in political decision-making processes (Bernhard, 2018). The Internet and social media allow participants to influence the activities of political authorities through online communication. The dramatic growth in online political discussions has occurred during the last twenty years. In this period, the use of online technologies has transformed one-way political communication into multimodal interaction (Tromble, 2018).

But observation of the latest political discussions online shows that most conversations are led without regard to the interlocutor. Some authors raise the question of practices of politeness and civility in online interaction and their impact on the quality of political discussion (Papacharissi, 2004); others, argue that social media are creating "echo chambers" where "citizens need not engage with those who make sense of politics in different ways" (Hinck, 2018, p. 215). Furthermore, anonymity and freedom on the Internet can lead to aggression, rudeness, and unwillingness of participants to listen to each other. Political discussions can transform into flaming or trolling and finally become an exchange of insults. This raises the question among some scholars: Is high-quality online interaction possible and can it facilitate democracy?

This type of questioning is carried out by scholars who work based on deliberative criteria to understand what results may come from these conversations and whether they follow minimum principles of reciprocity, reflexivity, mutual respect, rational consideration of points of view, explanation, and review of arguments, etc. Therefore, Marques and Martino (2016, p. 119) argue that "a deliberative framework of political conversations can lead to unrealistic expectations about how the conversation works." For that reason, "the analytical focus of the conversations can be more interesting if it seeks to reveal how conflicts, dissent, and disagreements are worked on in the interaction."

Based on that premise, we seek to contribute to studies on political participation with an analytical focus seeking to understand how interaction processes 
take place on candidates' Facebook pages, without making value judgments about the analyzed political conversations. This approach considers also how the affordances, architecture, and rules of this social networking site interfere with the interaction processes studied here.

To address the research objectives, we observed the interaction processes developed by electors and the candidate's campaign staff on Facebook, mainly in postings in the comments section. According to Stromer-Galley (2000, p. 114), there are two ways in which the Internet can improve democracy: "by promoting an increase in horizontal communication among people and an increase in vertical communication between people and political elites." While we do not know if this increase in online communication can improve democracy, following the purpose of this study, we tried to understand the characteristics of these processes in the Brazilian electoral context.

\section{Vertical and horizontal communication in political campaigns}

Depending on the direction of communication flow, two types of online interaction can be identified: horizontal communication between actors at the same level (e.g., electors) and vertical communication between communicators having not equal positions (e.g., electors, journalists, politicians).

Horizontal communication is considered in contemporary studies from different points of view. Some scholars understand it as online-talk among the groups of citizens trying to improve public policy in their countries (Constanza-Chock, 2006; Sørensen, 2016). They use social media (mostly Facebook and Twitter) as tools to communicate with each other. Although some scholars warn about a hazard of miscommunication or unproductive interaction between citizens through digital platforms (Dishon \& Ben-Porath, 2018), the phenomenon of using social networks for political conversations has made re- searchers argue that these platforms enable the formation of a new public sphere (Segaard \& Nielsen, 2013). In this sense, we agree with van Dijck (2012, p. 162), that "there is less need for articulating a 'new' sphere or spherical concept but more need for theorizing how this communicative space [Facebook, the authors] is contested by public, private, state, and corporate actors fighting to dominate the rules for social interaction." Moreover, "what is important to understand about social network sites is how they activate relational impulses, which are in turn input for algorithmically configured connections - relationships wrapped in code - generating a kind of engineered sociality" (van Dijck, 2012, pp. 161-162). Therefore, we examine here how the specificities of the platform (Facebook), where interactions take place, shape such interaction processes. Considering that, different from the "electronic brochures" of websites (Stromer-Galley, 2000), current campaigns should internalize a whole set of platform-specific features on social media to engage with electors (Stier et al., 2018). We consider also that there is a possibility of creative appropriation of the functionalities of social media (Marques \& Martino, 2016, p. 119), both in horizontal and vertical communication strategies.

Vertical communication, or communication between citizens and politicians, enables people to react to political elites' actions and inform them about their thoughts and wishes. In other words, it facilitates participation in the decision-making process. Although the Internet provides a great number of opportunities to communicate online, many writers find this kind of interaction doubtful. Stromer-Galley (2000) analyzed the results of studies exploring opportunities for political engagement offered by candidates' websites during the election campaigns. According to her research, only a few websites were interactive and provided feedback opportunities. She also points out that candidates tend to avoid interactions with electors for three main reasons: 1) the high costs of maintaining these channels and uncertainty about whether 
they are decisive for the electoral result; 2) the possibility of losing control of the communication flow; 3 ) the possible loss of ambiguity regarding the candidate's position on controversial topics. Therefore, Stromer-Galley (2000) refers to online interaction between politicians and citizens as a simulacrum of democracy that seduces individuals with mere appearances of communication and collectivity, while isolating them. Later studies investigating online political conversation confirmed this conclusion (Nielsen, 2011; Stromer-Galley \& Wichowski, 2011; Sweetser \& Weaver Lariscy, 2008). That was the state of the art ten years ago.

More recent studies show that politicians do not avoid interaction (Ceron, 2017), but prefer top-down communication. Possibly, it has not changed so much. According to Tromble (2018), most of politicians' social media activities take the form of one-way communication. Recent studies identify various factors influencing online interaction between politicians and the public: type of platform (Nelimarkka, Laaksonen, Tuokko, \& Valkonen, 2020), citizen demand (Tromble, 2018) and the platform's architecture (Bossetta, 2018; Stier et al., 2018).

\section{Methods}

Following the purpose of this research, we used a qualitative approach to analyze comments posted on the candidates' Facebook pages during the 2014 electoral process. The official Facebook pages of the three main presidential candidates were scrutinized by the first author - to carry out an "extensive and detailed analysis of the traits that characterize the case", e.g., the signs, which would be "the perceptible elements of the case to be studied" (Braga, 2008, p. 79). Thus, abductive approach was carried out to systematize our observations and formulate the evidence-based research case (Dubois \& Gadde, 2002). Abductive reasoning implies an intertwining relation between theoretical analysis and empirical observation. Different from deductive or inductive approaches, abductive pro- cess takes place through a “'back and forth' [movement, the authors] from one type of research activity to another" (Dubois \& Gadde, 2002, p. 555). Theory is actioned to analyze empirical data, while observations bring insights to rethink the theoretical framework in a process of mutual tension. It is important to note also that the collection of data and many of the reflections exposed here are the results of an empirical research carried out by the first author for her doctoral thesis (Maia, 2019).

The election campaign began on July 6, 2014, and initially included three main candidates: Dilma Rousseff (PT), Aécio Neves (PSDB), and Eduardo Campos (PSB). However, after the death of Campos in a plane crash on August 13, the Brazilian Socialist Party chose Marina Silva, his vice president candidate until that moment, to participate in the presidential elections. According to the pre-election polls, she moved to the front line along with the other two candidates. Therefore, the collection of empirical data for this research covers the period from August 20 to October 26, 2014 - the date when Silva got involved in the election until the second-round vote that marked the end of the elections.

Considering that this period was marked by the intense circulation of the content on the observed pages, we deem it pertinent to state the main candidate posts and their respective comments (29 posts on the page of Neves, 29 posts on the page of Rousseff and 20 posts on the page of Silva - totaling 78 posts, for a detailed overview see the Online Supplement). These represent the most relevant moments of this presidential campaign. The relevance was measured mainly based on the intensity of interactions that these posts generated. Television debates, for example, had immense repercussions on Facebook, generating hundreds of comments on the observed pages. We restricted our observations to the first 50 comments of each post (totaling 3900, collected from the 78 analyzed posts), sorted by relevance. The redundancy of the content in these first 50 comments justifies not extending the analysis into the quantitative collec- 
tion since our objective is to understand the diversity of comments, more than the relative proportions. The first fifty comments on each post are enough for the analysis proposed here because, apart from being the first ones posted, which facilitated their collection, they were also the comments that received more "likes" and "comments-reply" from users of the site. This shows that this selection of comments reflects the thoughts and ideas of participants.

After the collection and storage of the posts and their respective comments in text documents, the first author of this study enumerated these comments and moved on to the analysis of the communicative strategies and interactive processes carried out by the participants of those pages (electors / campaign teams). To analyze these empirical data, the ethnomethodological discourse analysis approach was chosen as a research method. Ethnomethodology was established by Harold Garfinkel in the 1960s (Moore, 2013). It is not a method itself, but, as Garfinkel puts it in a discussion with other scholars, "it is an organizational study of a member's knowledge of his ordinary affairs, of his own organized enterprises, where that knowledge is treated by us as part of the same setting that it also makes orderable" (Hill \& Crittenden, 1968, p. 10). In this sense, Rodrigues and Braga (2014) emphasize the analytical potential of the "ethnomethodological approach of discourse" for the explanation of the phenomena of discursive exchange, not only in face-to-face contexts but also on the Internet. The authors further explain that while a conventional discourse analysis takes an approach to discursive interactions as something complementary to the meaning of what is said, an ethnomethodological posture, in turn, considers that the meaning of what people say is closely related to the interactional context in which their talks took place. In our case, what matters is not just a study of power strategy engendered by candidates to persuade electors on Facebook, but mainly, what the participants do together, the interaction processes developed by them on these pages.

\section{Results}

In order to explain the interaction processes observed in the analysis, a model was developed through which we categorized the interactions into two major types: vertical communication and horizontal communication. Based on the conceptualization proposed by Stromer-Galley (2000) for the communication in these two dimensions, it will explain, on the one hand, what happens when the elector writes in the candidates' posts and when the campaign staff responds to these comments; and, on the other hand, what happens when electors interact with each other. At the end of this analysis, a table of this typology will be presented as a tool for summarizing observations.

\subsection{Vertical communication}

We identified some patterns in the communication between electors and the candidate's campaign staff. These patterns were organized into categories that will be explained and exemplified below. Since there is some reciprocity between what the electors comment on and what the candidates respond to, the interactions between these two poles will be analyzed together.

\subsubsection{Elector's compliments and candidate's acknowledgments}

One of the most common types of comments posted by the electors on the candidates' pages is one in which they make compliments to the candidates regarding their personality, government plan, or performance on the debates and campaign in general. In these comments they say such things as: "Congratulations, you are doing great!", regarding the candidate's performance during the debate. This type of message was answered with acknowledgments from the candidates. Also, it is important to highlight that only two candidates (Neves and Silva) usually answered the electors' comments. Rousseff's campaign staff rarely responded to comments. As most of the comments addressed to Rousseff remained unanswered, it seems like the electors were just talking among themselves. 
On the other hand, the question is not only whether participants were interacting with the candidates (actually with their team) or not. An important aspect of this case study is that electors were being invited to speak not just to the candidate but also to the "third group" - "them." This group ("them") consists of at least three types of people: silent participants (undecided electors), the peers, and electors who choose opposing candidates. Another possibility is that some campaign teams have infiltrated the debates in a disguised way, through false profiles that simulate the behavior of the common user to create discussions that can favor or attack certain candidates, with an appearance of popular opinion (Kovic, Rauchfleisch, Sele, \& Caspar, 2018; Maia, 2019). This does not compromise our analysis because the idea is to understand how electors and campaign teams develop communication strategies together with the objective of winning the elections.

\subsubsection{Electors' criticism against opposing candidates}

Another common type of comment is one in which the electors strongly criticize the opposing candidates, mostly regarding their personality, their party, or their government plan. This type of comment is responded to with a concordance comment from the candidate's campaign staff. They usually agree with their candidate's positive qualities or the opponents' mistakes, even when the elector's speech is prejudiced against minorities.

In a video where Neves speaks about denunciations of corruption in Petrobras (a semi-public Brazilian multinational petroleum corporation) during Rousseff's presidency, e.g., an elector comments that Neves is the only one whom she trusts and affirms that Brazilians need men and not women to govern the country: "It has already been proved that a woman as a president in Brazil does not work" (Regina, 2014). ${ }^{1}$ This statement was supported by

1 All the comments used in this paper were translated from Portuguese to English by the authors. more than a hundred Internet users who liked the comment. As mentioned before, Stromer-Galley (2000) says that loss of control is one of the common concerns shared by candidates regarding maintaining a comment section on their website. More skeptical electors may feel that the candidate shares the same ideas expressed in inappropriate messages posted by some extremist electors. However, in this case, the candidate's campaign staff took the risk and answered this statement, saying that "there is no more space for the amateurism of the current government," which was represented by president Rousseff at that period. This corroborates the statement of Stier et al. (2018) that the current online campaigns are micro-targeted, that is, they adapt their messages to specific audiences and act according to the logic of each social media platform. In this case, Neves operates according to Facebook's logic of "making friends," by agreeing with the comments of his electors to create ties with them.

Later, some women criticized this comment accusing it of sexism, but they were labeled as "petistas" (militants of the opposition party). Thus, the conversation did not develop. Making the author of divergent comments an enemy to be fought is one of the main strategies used by many commentators to avoid the need to present arguments to develop the debate. If the "others" are "our" enemy, they must be rejected, no matter what they say.

\subsubsection{Questions and answers on policy plans}

Among all the analyzed elector postings, those who used the comments section most often to ask questions about the candidate's government plan were Silva's electors. This happened because the candidate changed her government plan 24 hours after launching it, claiming a procedural flaw in the editing of the document. The change took place in the points that contemplated the demands of the LGBT public before. ${ }^{2}$ This led to many attacks

2 The change in the government plan was in relation to the statements that promised 
by opponents, who accused her of having changed the government plan in the light of criticism from the religious point of view since the candidate is evangelical. Moreover, in the face of persistent attacks by opponents, especially Rousseff, certain promises of Silva's campaign led to many doubts among electors. Thus, it was common for the electors to explore the candidate's social media platform to understand her positions on some issues. The team, at a certain point in the dispute, presented long answers with explanations about the candidate's government plan in the space provided for comments. But in general, both her and Neves' team regularly submitted short responses, followed by links to the campaign website. This shows the perception, among these campaign teams, that Facebook would be a space for ephemeral interactions, engagement, and participation, while the websites would be spaces of abundance of information (Maia, 2019).

\subsubsection{Candidates asking for support}

This category represents the comments in which electors offer help to the candidate's campaign or advice about the government plan, and the candidates ask for support of the campaign. Neves' electors, for example, tried to advise the candidate, mostly regarding what kind of performance and speech he should adopt during the campaign. One of them said, for example: "Ok Aécio [Neves], the upper and upper-middle class have already understood your political platform, and most of them have already decided to vote for you. How about start talking to the poor people using an accessible language for the masses?" (S. Lima, 2014).

Silva's electors, in turn, indicated what they were doing to contribute to the candidate's campaign: "I made myself stickers to put them on my family's vehicles" (Reis, 2014). Other electors summoned their peers to go to Rousseff's page to respond

1) support for the criminalization of homophobia and 2) the adoption of children by same-sex couples. After the change, the first promise was removed and the second toned down. the accusations her electors made against Silva: "we sincerely need to fight back on the Workers' Party Facebook page" (David, 2014). To this type of comment, the candidate's team responded with messages that had an imperative tone, propagandistic rather than dialogical ("Follow @Marina Silva," "Join us," "Participate"). On Facebook, the campaign staff can answer each person in a way that the response could reach everybody in general. Silva's team addressed the electors by name and at the same time took advantage of the medium's features, which allow a response addressed to one to become visible to all. So, the request for support to an elector could be extended to everyone.

Rousseff's electors produced some content to share on social media, driven by the intention to contribute to the candidate's campaign and responding to her team's call to post positive content for her. They published their life stories and personal memories, intertwined with previous and later political environments to the governments of Lula da Silva, Rousseff's predecessor, and Rousseff herself, to argue that their lives changed due to the social programs created by the Workers' Party. Thus, they presented rational and emotional arguments for the candidate's choice. They also shared texts, videos of mobilizations, songs, drawings, and all types of productions in favor of the candidate. Some of these amateur productions became part of the candidate's timeline on Facebook - thanks to the strategy of using the hashtag \#FaceDaDilma, which allowed the posts made on supporters' timelines to be found and shared by this candidate's campaign team. In one of these posts, reproduced below, the elector posted a selfie holding his diploma and wearing his university uniform. He told his life story in order to demonstrate concretely how the social programs developed by the Workers' Party had transformed his life and that of his family.

My family initially received Bolsa Família, ${ }^{3}$ as $80 \%$ of the families in my municipality did.

3 The Programa Bolsa Família (PBF) is a gov- 
Thanks to PRONAF [National Program for Strengthening Family Farming, the authors] credit lines, we got a better income and left the program. I went to study high school at a federal institute ... together with my older brother. At that time, my sister got a partial scholarship. Then, my brother and I got places at federal universities ... During these four years we lived on assistance grants (housing, food) and research grants. Nowadays, I have my diploma in my hand, and my brother is about to graduate. My other sister is taking a course through PRONATEC [National Program for Access to Technical Education and Employment, the authors]. We struggled a lot to "win in life," we are the first generation in the family with higher education, our parents haven't even finished elementary school. But if it weren't for the opportunities created in the last decade, we would most likely not be where we are. (Oliveira, 2014)

\subsubsection{Criticism and defense of candidate's performance in debates}

Each group of electors supporting the three main presidential candidates also endeavored to provide a kind of advice to them. Whenever the politician participated in a televised debate, for example, the commentators carried out analysis of the events to suggest what kind of behavior, subjects and approaches the candidate should adopt.

In these comments, electors discussed the position the candidate should have to face the opponents: "[Y]ou have to attack more and be more incisive" (Bandeira, 2014). From what appears to be an analysis of the circumstances of the dispute, an elector still warns: “[E]ither you [Neves] at-

ernment program introduced in 2003 by the then-president, Lula da Silva, a member of the Workers' Party. "Under PBF, low-income families receive cash transfers on the condition that, for example, they send their children to school and ensure they are properly vaccinated. The conditional cash transfer model successfully reduced levels of inequality and hunger - with significantly fewer people living below the poverty line - and closing the historical rural-urban gap" (Center for Public Impact, 2019). tack the candidates with ideas and facts or we will lose the election" (Bandeira, 2014). Neves' team, in turn, opted for an automated response, only thanking the elector for their suggestion.

In one of Silva's posts, the electors also suggested what kind of performance the candidate should have to face her opponents, and what kind of discourse she should use with the electors. They suggest that she should change her posture, which, in their opinion, demonstrated passivity and uncertainty. Some of them seem to have incorporated the imaginary that a political debate would be a kind of fighting ring, in which candidates must attack opponents. The marks of this vision are discernible in some words contained in one comment addressed to her post: "go to them," "you did not attack," "just agreed," "defense is (...) attack," "react" (Torres, 2014). The team responded to them with the irreducible defense of the candidate's policy-making way: "based on proposals, not on attacks. In a debate, not in a clash" (Silva, 2014). The other commentators who got into the conversation, continued adopting the position of "political consultants," analyzing the behavior of the candidate and suggesting how to continue the campaign.

\subsection{Horizontal communication}

In all the analyzed posts, the communication did not end with the candidate's response. Many other commentators got into the debate, disagreeing or agreeing with the initial comment, and others diverging completely from the subject that started the debate. This change of subject in the comments section is a symptom that the discourse does not circulate linearly. Thus, these horizontal communications are characterized by strong indetermination, the interaction is not typically point-to-point, but rather a diffuse interactivity (Braga, 2006). It is important to note that the architecture of Facebook supports this so that the comment space works in this diffuse and chaotic way. Besides, the ranking made by the website for the display of comments ends up favoring those more emotional and less rational, since they were the ones that received 
the most likes and responses (Zerback \& Wirz, 2021). Thus, the most controversial comments gained greater attention from users and, therefore, were ranked better by the algorithm. This ended up giving greater visibility to these messages - in a cycle that feeds back. This section will explain the categories listed as horizontal communication and explore the peculiarities of these diffuse interactions developed by citizens when they discuss politics on platforms such as Facebook.

\subsubsection{Discussing policy plans}

Silva's electors are those who used the comment section most often to discuss the candidate's campaign plans. This seems to happen partly because, as mentioned, this candidate made changes in her government plan. Neves' electors sometimes asked what he would do for a different group of citizens. These issues were often not answered by the candidate, so the electors themselves tried to give vague answers to the questions, or pointed out possible paths that the candidate should adopt to solve the demands of different groups of electors. Rousseff's electors, in turn, talked mainly about the social programs implemented by the Workers' Party and argued that the best thing for the country would be the continuation of the government program adopted by her. Silva's and Neves' electors also criticized Rousseff's social programs, especially Bolsa Família [a social welfare program, the authors], and they split off into arguments about whether the program should continue.

\subsubsection{Discussing candidates' personality}

Both the electors for a candidate and the electors for opponents tried to create categorizations for the presidential candidates. Rousseff's electors, for instance, report her to be a mother, they usually called her "Dilmãe" (a word that they created from the junction of Dilma plus mother). The opponent's electors, in turn, accused her of being "a thief, a corrupt ... a terrorist" (Alves, 2014). This comment was posted in response to another that pointed out Neves' lack of elegance against Rousseff during a presidential debate (Rodrigues,
2014). Thus, her electors accused the opposing candidate and his electors of being aggressive and disrespectful.

To Silva's electors, she was a savior. To some of them, a strong woman. To others, she was too delicate and uncombative, as mentioned in sub-chapter 5.1.5. For example, an elector says: "When you [Silva] speak slowly, you show insecurity about what you are talking about, as if you don't know about the subject" (Torres, 2014). Some agree with this criticism, while others disagree, arguing that the candidate's more peaceful tone demonstrated that she was "different, even in the way she spoke and expressed herself" (Sscpam, 2014), which would be something positive for them. For those that did not choose her, she was indecisive, a puppet of the bankers, in the opinion of Rousseff's electors. In a post in which Silva alleged that her proposal of autonomy of the Central Bank consisted of preventing any party or group of interest from using that institution to benefit themselves, an elector opposed to the candidate, questioning: "No bank, Marina? Not even Itaú, a bank which your campaign advisor is heiress? It makes me laugh" (Leal, 2014). Faced with this type of criticism, other electors defended Silva claiming that: "Yes, the coordinator of the Government Program is one of the heirs of Banco Itaú, but what links her to Marina is education. Fruit of her career as an educator and funder of social and sustainability projects" (Feitosa, 2014). In another post, in which the candidate claimed to never have mixed religion and politics, a critic pointed out that "a tweet by Malafaia [evangelical pastor, the authors] was enough for her to change her government plan" (Lucas, 2014). That post was answered by one of her supporters, who stated:

Marina did not submit to Silas Malafaia, nor did she retreat from her positions, which have been the same since 2010: equal rights between homo-affective and hetero-affective regarding civil union, with sharing of health insurance, sharing of assets and the right to adoption. She just doesn't use the word “marriage" to avoid problems with an electorate of 
tens of millions, many of whom would see it as a threat to religious practices. (Souza, 2014)

In the words of the Neves' electors, in turn, Silva was an auxiliary line of the Workers' Party. In one of the posts by Neves during the first round, for example, an elector asked him to show that Silva and Rousseff "are the same thing, the result of the same ideology" (Riera, 2014). He, in turn, was a hero for his electors. One of them, for example, pointed out that Neves was her hope to "save Brazil from the clutches of petralhas [members of the Workers' Party, the authors], the mafia, the criminal organization, the terrorists, the communists" (Regina, 2014). Another elector responded to that comment asking: "And would Aécio be our Savior??? I don't doubt what PT is capable of... but believing that Aécio would do it differently makes me want to laugh out loud! Good luck Brazil" (Kowaltschuk, 2014). Faced with that question, an elector from Neves replied:

Aécio may not be the savior of the homeland because [such thing, the authors] doesn't exist! But he is the most prepared [candidate, the authors] to govern the country right now! He is the only candidate who has concrete plans to fight violence, corruption, to improve Brazil's image internationally! (Nunes, 2014)

Nevertheless, for those who chose other candidates, Neves represented the rich people and was not concerned about the needs of the socially marginalized groups.

\subsection{3 (Not) Discussing the country's situation in general}

Rousseff's electors argued that the country had improved a lot when the presidency of the republic was under Workers' Party control and that betting on another government, represented by Neves or Silva, would put all these improvements at risk. Meanwhile, electors of both contenders to Rousseff argued that corruption, supposedly preponderant in the Workers' Party, was driving the country into chaos and only the candidates they chose could change the direction of the nation. When they talked to each other they agreed on these arguments. When they talked to electors that chose opposing candidates, they usually started by discussing the country, but soon they tried to use an ad hominem strategy (Schopenhauer, 2009) or sought other ways to not discuss the specific subject matter.

In a post in which the official page of Rousseff shares the testimony of an elector, for instance, an opponent elector tried to disqualify her electors, saying they were "the shame of this nation," (Rangel, 2014) and accused the Workers' Party of being corrupt. In response, an elector of Rousseff points out the denunciations that exist against the PSDB, the main opposition party to the Workers' Party. The strategy was: If the opponent elector speaks ill of whom I stand in favor, I will speak ill of whom he probably chooses. The next elector who got into the debate started to attack the sources used by the Internet user against Rousseff. In the latter two cases, neither of both electors attacked the arguments of the opposing commentary, and in all other comments that follow the same logic is observed. This approach is not necessarily exclusive to this group since this strategy could also be found in the comments of the pages of the three candidates in question. The fact is that, sometimes, the discussion of the country's situation is put aside in favor of the exchange of mutual accusations and attempts to disqualify the other.

\subsubsection{Supporting themselves and insulting each other}

A common strategy among all the electors is to say or share what they are doing to help the candidate they chose in order to incentivize their peers to do the same. A Neves' elector, for instance, posted:

Word of mouth works, folks! I printed material about Aécio's achievements and his biography. I started distributing yesterday. I spoke in the elevator to people I knew who were in doubt and, also, porters, taxi drivers and individuals who were in a print shop. Things seem to be going well. Social media isn't everything. 
You need a little printed material and go by word of mouth. (Perfeito, 2014)

Faced with this discourse, several electors felt instigated to also contribute to the campaign and asked where they could get the material to distribute in their neighborhoods as well. The intention in sharing the experience of militancy in support of the candidacy is precisely this: to generate the contagion effect and make others feel impelled to contribute in some way to the campaign as well.

Silva's electors, in turn, shared some strategies to help the candidate's campaign: "We have to go on social networks to support Marina Silva, who is being slandered! Let's go to the Facebook pages of Folha de São Paulo, Veja, O Globo, Estadão, and others [journalism companies, the authors] with national repercussions!" (Hellen, 2014).

In addition, whenever any elector produced something (an artistic creation or a comment that substantiated the vote in question, for example) in favor of the campaign that united them, the other electors of that group tried to support and congratulate their peers, as happened when Rousseff's Facebook page shared a piece of art produced by an elector in favor to her and the other electors accomplished the creator of this artwork: "it's very beautiful, if I were Dilma Rousseff I would keep it as a souvenir" (Coutinho, 2014). This type of strategy denotes an effort to strengthen the ties among the members of the group, to make those who are part of it and collaborate with it feel important and valued in that group. On the other hand, the presence of electors who opted for presidential opponents on the official pages of the other candidates was strongly opposed by the group that chose that candidate. On the same Facebook page, an elector from Neves criticized the artwork of Rousseff's elector: "My God, what an ugly thing... I was even scared when I saw ..." (Azevedo, 2014). This was answered by a Rousseff's elector request for him to leave that space, as if it belonged only to them. This is one of the characteristics of the formation of an "us versus them" perspective in the analyzed pages.

\subsection{5 "Us versus them"}

Each group of electors acts in the sense of "demarcating" that place as its own to form bonds only with each other and with the candidate they have chosen for the presidency. The comments presented above, which refer to the artistic production of an elector in favor of the candidate Rousseff, demonstrate that electors understand the pages of their candidates as a space that belongs only to them. Therefore, they believe that opponents should withdraw from that space along with their arguments against the candidate who owns the page.

It is also common to try to create a characterization for that group of "us" regarding "them." As an example, we have this comment posted on Rousseff's Facebook page:

\begin{abstract}
The difference between Dilma's electors [us, the authors] and Aécio's electors [them, the authors] is in argumentative capacity, we do not need to offend anyone, we defend our vote without denigrating the other. Respect for others, people. If you do not agree, go to the page of your candidate [and] manifest support, lowering the level of the debate this way, you will not get anything here. (M. Lima, 2014)
\end{abstract}

\subsubsection{Justifying one's decision for a candidate and judging on other's decisions}

The "we," implicit in the speech of Neves' electors, are those with reasoning ability, who have already opted for the candidate. The "them" would be "the poor people / the mass," as it can be observed in the comment posted by S. Lima (2014) and used as an example in chapter 5.1.4. On the other hand, the "we" of Rousseff would be "the people," and "them" would be "the elite." One of Rousseff's electors, for example, responded to a comment made by another elector, who informed how the Workers' Party's social programs had changed his life, with the following statement: "Con- 
gratulations on the story Bruno, this is what they [the rich people, the authors] hate the most, people having more opportunities" (Mafra, 2014). The "us" of Silva, in turn, are those who want the "new" while "them" are those who chose more of the same: PT or PSDB. One of Silva's electors argues, for example: "It is incredible and laughable the amount of abuse addressed to Marina by Workers' Party and right-wing blogs' supporters. [...] Should we comply with the corruption scandals of the PSDB [Neves' party, the authors] and PT [Rousseff's party, the authors]?" (Goldenstein, 2014). In establishing these divisions, prejudiced patterns were created to explain the motivations of each group of electors: Rousseff's electors would be driven by ignorance and the need for welfare programs (such as Bolsa Família); Neves' electors would be driven by hatred of the poor and the will to maintain class divisions; and those that chose Silva would be naive to believe that she would, on the one hand, govern for the poor Brazilians or, on the other hand, be different from the PT. In this sense, Slimovich (2012) explains that this type of posture is common among politicians because democratic disputes demand the construction of an antagonistic element with which it cannot be reconciled. In the case analyzed here, electors see themselves as part of the campaigns, so they adopt the same kind of warlike behavior demonstrated by the majority of the candidates. They end up treating their compatriots as if they were enemies, just because they have different demands or ideology (Maia, 2019).

\section{Discussion}

To synthesize our findings, the two types of online interaction (vertical and horizontal) are organized in two tables, which articulate the communication processes developed by electors among themselves and with the candidate's campaign staff.

In the first table, we consider the messages that were sent from electors to candidates that they apparently chose. We tried to create a correspondence between the messages posted by the electors and the responses sent by the candidate's campaign staff. It should be noted that the comments directed against the candidate were never answered by the campaign

\section{Table 1: Vertical communication}

\begin{tabular}{l|l}
\hline \multicolumn{1}{c|}{ Electors to candidate } & \multicolumn{1}{c}{ Candidate to electors } \\
\hline Compliments & $\begin{array}{l}\text { Acknowledgments } \\
\text { Concordance (about their positive qualities or opponent's mistakes) } \\
\text { Electors' criticism against opposing candidates } \\
\text { Asking questions about policy plans }\end{array}$ \\
Trying to help the candidate & $\begin{array}{l}\text { Candidates asking for support } \\
\text { Criticizing candidate's performance in debates }\end{array}$ \\
\hline
\end{tabular}

Table 2: Horizontal communication

\begin{tabular}{|c|c|}
\hline Electors to electors & Electors to electors of opponent candidates \\
\hline Discuss policy plans & Discuss policy plans \\
\hline $\begin{array}{l}\text { Discuss candidates (personality) } \\
\text { a) Rousseff is like a mother } \\
\text { b) Silva is a savior } \\
\text { c) Neves is a hero, the only hope for the country }\end{array}$ & $\begin{array}{l}\text { Discuss candidates (personality) } \\
\text { a) Rousseff is corrupt, a liar } \\
\text { b) Silva is someone indecisive, a puppet } \\
\text { c) Neves is a representative of the economic elites }\end{array}$ \\
\hline (Not) Discussing the country's situation in general & (Not) Discussing the country's situation in general \\
\hline Trying to support themselves & Insulting each other \\
\hline "Us versus them" (friends and enemies) & Us versus them (friends and enemies) \\
\hline Explaining and defending their reasons to choose that candidate & Judging on other's decisions \\
\hline
\end{tabular}


staff. One explanation for this phenomenon of non-response to critics lies in Facebook's operating logic. If candidates respond to a comment directed against them, the comment will gain prominence, and then this negative message will be at the top of the comment display list for that post, which can be detrimental to the candidate - that is why they usually "preach to the converted" (Stier et al., 2018, p. 55). In this context, Marques and Martino (2016, p. 126) emphasize the importance of "considering the technical aspect and the interface design (discursive architecture) as one of those responsible for the architecture and the functioning of the debate." Besides, Stromer-Galley (2000) points out that if, on the one hand, the coordination of the campaigns shows a constant effort to adapt to online platforms, on the other hand, campaigns also demonstrate a certain insecurity in losing control of the flow of information, and thus end up harming the candidate.

Maybe since they are aware of that, when an elector posts negative comments on a candidate's page he seems to direct his message to that candidate's electors, hoping to be answered by those electors rather than by the candidate's campaign staff. Thus, this strategy results, as a consequence, in a flow of horizontal communication between the electors supporting opposing candidates. It corresponds with Sørensen's (2016) explanation of how horizontal talk often begins. He concludes that conversations between citizens start after some of the political posts that the politicians do not re-enter (Sørensen, 2016).

It is also important to highlight that the undecided electors are a difficult category to analyze because they rarely declared themselves as undecided. Even in comments with questions addressed to the campaign staff in most cases, the electors say first: "I'll vote for you, but I need to ask (...)." So, in this case, undecided electors rarely made remarks that would allow an investigation of their behavior.

In a paper published in 2000 , and used as a reference in this study, Stromer-Galley reported the results of her interviews with campaign teams and her analysis of
U.S. candidate websites in 1996 and 1998 to explain why these candidates avoided online interactions with citizens. The author glimpses the democratic possibilities arising from interactions between people and political elites: "An interactive forum such as public bulletin board could create an environment in which people would ask specific questions to the candidate or make comments criticizing a position or action" (2000, p. 125). However, she also elucidates that having interactive forums can represent a risk to the candidates because if they give too many details about their plan, they may lose the ambiguity necessary to win the election. So, for instance, it was important for Silva to keep the vote of the evangelical group and, at the same time, to ensure the LGBT public that she would support their demands. Still, answering these questions and giving details regarding her government plan seemed to be a risk worth taking. This use of the candidate's Facebook page as a space to address questions about her government plan illustrates some positive role for online political communication, such as providing new information (Bernhard, 2018; Segaard \& Nielsen, 2013) and involving new people in the electoral process (Sørensen, 2016).

Since the electors believe that their candidates could solve the country's problems, they engage in activities online and in person. It seems that they feel co-responsible for the success of the campaign. In addition, they seem to know that they were not talking with the candidate, but about them, since all the answers were posted by the candidate's campaign staff. This was clear by the assigned messages that ended with the hashtag \#team of Dilma or Aécio or Marina. However, the electors still acted as they were talking with the candidate, with a friend. It is worth remembering that maintaining friendship bonds is one of the premises of Facebook, a social network that exists due to the act of "adding" friends (through profiles) and interacting with them (Stier et al., 2018).

To create a sense of closeness to the elector, candidates used colloquial politics and expressed themselves through home- 
made videos. Through the analysis, it was possible to observe that the campaign teams were more focused on influencing electors to act as volunteers than on discussing the social and economic problems to be faced. Electors, in turn, in many situations, addressed politicians as if addressing a friend: giving advice on how the candidate should act or speak, asking questions, praising, criticizing, making suggestions, etc. This contradicts the assumptions of Erikson (2008, p. 4) to whom "politics is not a location of friendship; rather, it is a location of debate, argument, representation, and legislation. While friendship is traditionally a function of the private sphere, politics are a function of the public sphere." Nevertheless, it is worth mentioning the reflections proposed by van Dijck (2012), who considers that social networks not only cause transformations in the public, private and corporate spheres but, above all, operate a complex interpenetration of spheres, which typifies our contemporary culture. Therefore, it is understandable that these electors did not perceive distinctions between acting as friends of peers or as friends of the candidate / campaign team. As the interactional exchanges take place in the same space, reserved for comments, these hierarchies end up being left aside - horizontal and vertical communication develop there simultaneously. In the case of Rousseff, however, there was no such exchange between staff and electors in the comments. While not responding frequently to electors, the campaign team developed other interactive strategies, such as sharing the creations and testimonies of electors. This demonstrates the creative use of social media by the campaign of this candidate since the exhibition of content produced by amateurs together with that produced by specialists was something unusual until that moment in the Brazilian presidential elections.

On the other hand, responsiveness is certainly something that seems to be a concern among the electors. Most of the citizens who expressed their thoughts on the candidate's Facebook page also demanded communication with their lead- ers after the election period. One of Neves' electors, for instance, says: "Aécio, continue communicating with us through social media after you became president!!!" (Schelb, 2014). In any case, the candidates analyzed did not completely avoid interaction and there was responsiveness in all the pages observed since the unanswered comments by campaign teams lead to conversations between electors.

In these conversations, the analyzed electors employed the following communication strategies: the personal attack on the person who wrote the comment or on the candidate considered as an enemy; the attack on the sources presented by the opponent; and the focus on only one point of everything that was stated by the other. When this last strategy was used, the initial theme of the conversation shifted to several other subjects, as each commentator "entered" the discussion and highlighted a single point in any of the messages written before his. What resulted in the absence of continued interaction, in a fragmentation of the speeches and themes - which overlapped each other and spread. In this context, discussions lose focus as soon as they start.

Stromer-Galley (2000, p. 116) argues that "similar to civic network researchers, I hold optimism that the Internet can offer a public space for rational-critical debate outside or alongside consumer society." The observed political conversations among electors are not just a "rational-critical debate," but a mix of mutual support, disrespect, incivility, the exchange of insults and accusations. Sometimes we could observe fandom behavior (Erikson, 2008), or in short, the effort to support or damage not only the image of the candidate of their preferences or dislikes, but also the group of like-minded, or electors who made a different choice, respectively. In this kind of context, instead of constituting an "interactive forum," as predicted by Stromer-Galley (2000), an increased reliance on social media may create "closed systems of meaning-making and interaction resembling echo chambers" (Hinck, 2018 , p. 215). This is a consequence of the algorithmic configurations of social net- 
working sites that tend to generate a personalized information universe for each user, through the repetition of more and more of the same type of content already consumed (Pariser, 2011).

However, it is worth noting that even if the algorithm shows only content which users have previously interacted with, they still have the possibility of accessing new content and pages from people they do not "like" or "follow." Our analysis showed that there is in fact interaction among the three groups of electors. Even if this conversation is carried out through exchange of insults and incivility, there is still exposure to ideologically crosscutting viewpoints.

In this sense, research conducted by Cardenal, Aguilar-Paredes, Cristancho and Majó-Vázquez (2019), Flaxman, Goel and Rao (2016) as well as Bakshy, Messing and Adamic (2015) corroborate the need for a more critical view on echo chambers and filter bubbles interpretation. A study on online political information consumption in Spain has shown that, although users spend more time on consuming content they agree with, they generally "engage in considerable cross-partisan media exposure" (Cardenal et al., 2019, p. 360). A research conducted by Bakshy et al. (2015, p. 1130) "examined how 10.1 million U.S. Facebook users interact with socially shared news" and showed that "compared with algorithmic ranking, individuals' choices played a stronger role in limiting exposure to cross-cutting content." They also pointed out that "social media expose individuals to at least some ideologically crosscutting viewpoints" (Bakshy et al., 2015, p. 1131-1132), even though the quality of these interactions may be questionable. Like those authors, our interest was to analyze the phenomenon in its specificities, without making a judgment on the normative value of political crosscutting exposure.

\section{Conclusions}

Even though the comments section is used by electors to publish messages of encouragement and compliments to the candidates or offenses to the opponents, it is still important to analyze that material because electors also pose questions, discuss the country's situation, and try to get involved in the electoral process. Through the examination of the comments section of the three pages analyzed, we could observe that some electors occupied the comment session to engage in discursive exchanges involving micro-arguments, life testimonies, and different points of view. Despite the fandom behavior, pointed out by Erikson (2008), the analysis of the data collected in this research revealed that the affectivity presented in the comments can often be accompanied by concrete reasons for choosing one or another candidate. Emotions, in these cases, are mixed with the rational debate of ideas.

Our analysis has focused only on the most essential characteristics of online interaction in the election process. We did not examine the general deliberative quality of the conversations taking place online. Since much of the research regarding political conversations uses a quantitative approach to data collection and analysis, studies dealing with the peculiarities of political conversation are needed. This particular topic should be the focus of further research for both Brazilian and international researchers.

We hope this paper encourages other researchers to continue investigating the strategies of online interaction and political conversations in social media. In this regard, the two tables in which we organized the data in categories for vertical and horizontal communication, can be used as a framework for further research. This framework can serve as a tool to analyze types of online interaction between participants in an online political communication process.

It should also be noted that, by investigating how the possibilities of horizontal communication among people and vertical communication between electors and political elites are used, we can offer better suggestions for people regarding the use of digital media in democratic processes. However, we know that better use of the Internet in the election process is not 
something that could be decided only by the electors themselves. It is important also that the politicians and social media platforms, like Facebook, employ the technology to improve democracy and not to manipulate citizens' decisions, and follow through to address concerns about ethics and transparency. These are challenges and responsibilities that should be shared among all civil society members.

\section{Acknowledgements}

We would like to especially thank Professor José Luiz Braga, supervisor of the thesis that led to the collection of the data and many of the reflections exposed here. We also would like to thank to the financial support provided by the Brazilian Coordination for the Improvement of Higher Education Personnel (CAPES) and Fulbright.

\section{Conflict of interest}

The authors declare no conflict of interests.

\section{Supplementary Material}

Supplementary material for this article is available online in the format provided by the authors (unedited). https://www.hope.uzh.ch/scoms/article view/j.scoms.2021.02.003

\section{References}

Alves, W. (2014, October 17). Comment [Rousseff's Facebook page]. Retrieved from https://www.facebook.com/SiteDilmaRousseff/videos/772541039466156/?comment_id=772596386127288\&reply_ comment_id=772729386113988\&total_comments=183\&comment_tracking=\%7B\%22tn\%22\%3A\%22R9\%22\%7D

Arnaudo, D. (2017). Computational propaganda in Brazil: Social bots during elections. In S. Woolley \& P. N. Howard (Eds.), Working Paper, 8. Oxford, UK: Project on Computational Propaganda. Retrieved from https://blogs.oii.ox.ac.uk/politicalbots/ wp-content/uploads/sites/89/2017/06/ Comprop-Brazil-1.pdf

Azevedo, L. M. (2014, October 25). Comment [Rousseff's Facebook page]. Retrieved from https://www.facebook.com/SiteDilmaRousseff/posts/788652744521652?reply_comment_id=789540051099588\&total_comments $=63$

Bakshy, A., Messing, S., \& Adamic, L. A. (2015). Exposure to ideologically diverse news and opinion on Facebook. Science, 348(6239), 1130-1132.

Bandeira, B. (2014, September 2). Comment [Neves' Facebook page]. Retrieved from https://www.facebook.com/AecioNevesOficial/videos/825035207541362/?comment_id=825042990873917\&offset=0\&total_comments $=1148 \&$ comment_tracking=\%7B\%22tn\%22\%3A\%22R9\%22\%7D

Barifouse, R. (2014, October 29). Eleições 2014: Novos hábitos criam pleito mais conectado do mundo [Elections 2014: New habits create the world's most connected election] $B B C$. Retrieved from http://www.bbc.com/portuguese/noticias/2014/10/141028_eleicoes2014_internet_rb

Bernhard, L. (2018). What prevents knowledge inequalities among citizens from increasing? Evidence from direct-democratic campaigns in Switzerland. Studies in Communication Sciences (SComS), 18(1), 103-116. https://doi.org/10.24434/j. scoms.2018.01.007

Bimber, B. A., \& Davis, R. (2003). Campaigning online: The Internet in U.S. elections. New York, NY: Oxford University Press.

Bossetta, M. (2018). The digital architectures of social media: Comparing political campaigning on Facebook, Twitter, Instagram, and Snapchat in the 2016 US election. Journalism \& Mass Communication Quarterly, 95(2), 471-496. https://doi. org/10.1177/1077699018763307

Bourne, P. A. (2010). Unconventional political participation in a middle-income developing country. Current Research Journal of Social Sciences, 2(3), 196-203.

Braga, J. L. (2006). Sobre “mediatização" como processo interacional de referência [On "mediatization" as an interactional process of reference]. Conference Proceed- 
ings of the XV Encontro Anual da Compós, 1-16. Retrieved from http://www.compos. org.br/data/biblioteca_446.pdf

Braga, J. L. (2008). Comunicação, disciplina indiciária [Communication, evidentiary discipline]. Revista Matrizes, 1(2), 73-88. https://doi.org/10.11606/issn.1982-8160. vli2p73-88

Brazilian Internet Steering Committee. (2014). Survey on the use of information and communication technologies in Brazil - 2014. São Paulo: CGI.br. Retrieved from https:// www.cetic.br/media/docs/publicacoes/2/ TIC_Domicilios_2014_livro_eletronico.pdf

Cardenal, A. S., Aguilar-Paredes, C., Cristancho, C., \& Majó-Vázquez, S. (2019). Echo-chambers in online news consumption: Evidence from survey and navigation data in Spain. European Journal of Communication, 34(4), 360-376. https://doi. org/10.1177/0267323119844409

Center for Public Impact. (2019). Case study on Bolsa Família in Brazil. Retrieved from https://www.centreforpublicimpact.org/ case-study/bolsa-familia-in-brazil

Ceron, A. (2017). Social media and political accountability: Bridging the gap between citizens and politicians. Basingstoke, UK: Palgrave Macmillan.

Constanza-Chock, S. (2006). Analytical note: Horizontal communication and social movements. Retrieved from http://web. mit.edu/schock/www/docs/horizonal\%20 communication\%20and\%20social\%20 movements.pdf

Coutinho, C. (2014, October 25). Comment [Rousseff's Facebook page]. Retrieved from https://www.facebook.com/SiteDilmaRousseff/posts/788652744521652?reply_comment_id=789540051099588\&total_comments=63

David, A. (2014, September 12). Comment [Silva's Facebook page]. Retrieved from https://www.facebook.com/marinasilva. oficial/photos/a.144793905532248.25658. $126351747376464 / 858448407500124 /$ ? type $=3 \&$ comment_id $=8584647241$ 65159\&reply_comment_id=85894293 4117338\&total_comments $=55 \&$ comment _tracking=\%7B"tn"\%3A"R9"\%7D

Dishon, G., \& Ben-Porath, S. (2018). Don't @ me: Rethinking digital civility online and in school. Learning, Media and Technolo- gy, 43(4), 434-450. https://doi.org/10.1080 /17439884.2018.1498353

Dubois, A., \& Gadde, L.-E. (2002). Systematic combining: An abductive approach to case research. Journal of Business Research, 55(7), 553-560. https://doi.org/10.1016/ s0148-2963(00)00195-8

Erikson, E. (2008). "Hillary is my Friend": MySpace and political fandom. Rocky Mountain Communication Review, 5(1), 3-16.

Feitosa, L. (2014, September 11). Comment [Silva's Facebook page]. Retrieved from https://www.facebook.com/ marinasilva.oficial/photos/a.1447939055 32248.25658.126351747376464/858448 $407500124 /$ ?type=3\&comment_id=8584 64724165159\&reply_comment_id $=858532$ 684158363\&total_comments=55\&comment_tracking $=\% 7 \mathrm{~B} \% 22 \mathrm{tn} \% 22 \% 3 \mathrm{~A} \% 22$ R9\% $22 \% 7 \mathrm{D}$

Flaxman, S., Goel, S., \& Rao, J. M. (2016). Filter bubbles, echo chambers, and online news consumption. Public Opinion Quarterly, 80(Special Issue), 298-320. https:// doi.org/10.1093/poq/nfw006

Goldenstein, S. (2014, August 28). Comment [Silva's Facebook page]. Retrieved from https://www.facebook.com/marinasilva. oficial/photos/a.144793905532248.25658. $126351747376464 / 848287371849561 /$ ? type $=3 \&$ comment_id $=848301311848167$ \&offset=0\&total_comments $=1836 \&$ com ment_tracking=\%7B\%22tn $\% 22 \% 3 \mathrm{~A} \% 22$ R9\% $22 \% 7 \mathrm{D}$

Harlow, S. (2013). It was a Facebook revolution: Exploring the media narratives of the Egyptian protests. Revista de Comunicación, 12, 59-82.

Hellen, V. (2014, September 3). Comment [Silva's Facebook page]. Retrieved from https://www.facebook.com/ marinasilva.oficial/photos/a.1447939055 32248.25658.126351747376464/8584484 07500124/?type=3\&comment_id=858464 724165159\&reply_comment_id=858532 684158363\&total_comments=55\&com ment_tracking $=\% 7 \mathrm{~B} \% 22 \mathrm{tn} \% 22 \% 3 \mathrm{~A} \% 22$ R9\% $22 \% 7 \mathrm{D}$

Hill, R. J., \& Crittenden, K. S. (Eds.). (1968). Proceedings of the Purdue symposium on ethnomethodology. Lafayette, IN: Purdue Research Foundation. Retrieved 
from https://aiemcanet.files.wordpress. com/2010/07/purdue.pdf

Hinck, E. A. (2018). 2016: Not a normal campaign. Communication Quarterly, 66(2), 214-221. https://doi.org/10.1080/0146337 3.2018 .1441162

Kovic, M., Rauchfleisch, A., Sele, M., \& Caspar, C. (2018). Digital astroturfing in politics: Definition, typology, and countermeasures. Studies in Communication Sciences (SComS), 18(1), 69-85. https://doi. org/10.24434/j.scoms.2018.01.005

Kowaltschuk, I. (2014, September 6). Comment [Neves' Facebook page]. Retrieved from https://www.facebook.com/AecioNevesOficial/videos/827934893918060/?comment_id $=828074443904105 \&$ offset $=0$ \& total_comments $=15607 \&$ comment_tracking=\%7B\%22tn\%22\%3A\%22R\%22\%7D

Leal, S. (2014, September 11). Comment [Silva's Facebook page]. Retrieved from https:// www.facebook.com/marinasilva.oficial/ photos/a.144793905532248.25658.12635 1747376464/858448407500124/?type = 3\&comment_id $=858464724165159 \&$ reply_comment_id=858532684158363\&total_comments $=55 \&$ comment_tracking= \%7B\%22tn\%22\%3A\%22R9\%22\%7D

Lima, M. (2014, October 24). Comment [Rousseff's Facebook page]. Retrieved from https://www.facebook.com/video. php?v=785658981487695\&reply_comment_id=785920844794842\&total_comments $=296$

Lima, S. R. (2014, August 30). Comment [Neves' Facebook page]. Retrieved from https:// www.facebook.com/AecioNevesOficial/ videos/823230981055118/?comment_ id $=823350311043185 \&$ reply_comment_ id $=823353167709566 \&$ total_comments $=73 \&$ comment_tracking $=\% 7 \mathrm{~B} \% 22 \mathrm{t}-$ n\%22\%3A\%22R9\%22\%7D

Lucas, S. (2014, September 12). Comment [Silva's Facebook page]. Retrieved from https://www.facebook.com/ marinasilva.oficial/photos/a.8584923274 95732.1073741870.126351747376464/ 858595390818759/?type=3\&comment_id $=859453594066272 \&$ offset $=0$ \&total comments $=207 \&$ comment_tracking=\%7B $\% 22$ tn $\% 22 \% 3 \mathrm{~A} \% 22 \mathrm{R} 3 \% 22 \% 7 \mathrm{D}$

Mafra, A. (2014, August 23). Comment [Rousseff's Facebook page]. Retrieved from
https://www.facebook.com/DilmaRousseff/videos/727950180591909/?_tn__=\%$2 \mathrm{CO}$

Maia, L. R. H. (2019). A política dos eleitores no Facebook dos candidatos: Uma análise de dispositivos interacionais construídos nas eleições presidenciais de 2014 [Elector politics on candidates' Facebook page: An analysis of interactional dispositifs built in the 2014 presidential elections] (Doctoral Dissertation Thesis). Graduate Program in Communication, Unisinos, São Leopoldo-RS. Retrieved from http:// www.repositorio.jesuita.org.br/bitstream/ handle/UNISINOS/8699/L\%c3\%addia\%20 Raquel\%20Herculano\%20Maia_.pdf?sequence $=1$ \&isAllowed $=y$

Marques, Â., \& Martino, L. M. S. (2016). Mídia, ética e esfera pública [Media, ethics and the public sphere]. Belo Horizonte, Brazil: PPGCOM UFMG.

Moore, R. J. (2013). Ethnomethodology and conversation analysis: Empirical approaches to the study of digital technology in action. In S. Price, C. Jewitt, \& B. Brown (Eds.), The Sage Handbook of Digital Technology Research (pp. 217-235). London, UK: Sage.

Nelimarkka, M., Laaksonen, S., Tuokko, M., \& Valkonen, T. (2020). Platformed interactions: How social media platforms relate to candidate-constituent interaction during Finnish 2015 election campaigning. Social Media + Society, 6(2), 1-17. https://doi. org/10.1177/2056305120903856

Nielsen, R. K. (2011). Mundane internet tools mobilizing practices, and the co-production of citizenship in political campaigns. New Media \& Society, 13(5), 755-771. https://doi. org/10.1177/1461444810380863

Oliveira, W. A. (2014, October 20). Comment [Rousseff's Facebook page]. Retrieved from https://www.facebook.com/SiteDilmaRousseff/posts/779533175433609?comment_id=779561345430792\&offset=0\&total_comments $=2475$

Papacharissi, Z. (2004). Democracy online: Civility, politeness, and the democratic potential of online political discussion groups. New Media \& Society, 6(2), 259-283. https://doi. org/10.1177/1461444804041444 
Pariser, E. (2011). The filter bubble: What the Internet is hiding from you. London, UK: Penguin Books.

Perfeito, A. (2014, September 11). Comment [Neves' Facebook page]. Retrieved from https://www.facebook.com/AecioNeves Oficial/videos/830903383621211/?comment_id=830921553619394\&offset=0\&total_comments $=1725 \&$ comment_tracking $=\% 7 \mathrm{~B} \% 22 \mathrm{tn} \% 22 \% 3 \mathrm{~A} \% 22 \mathrm{R} 9 \% 22 \% 7 \mathrm{D}$

Rangel. (2014, October 20). Comment [Rousseff's Facebook page]. Retrieved from https://www.facebook.com/SiteDilmaRousseff/posts/779533175433609?reply_comment_id=779575848762675\&total_comments $=59$

Regina, S. (2014, September 6). Comment [Neves' Facebook page]. Retrieved from https://www.facebook.com/AecioNevesOficial/videos/827934893918060/?comment_id $=828108017234081$ \&offset $=0$ \& total_comments $=15607 \&$ comment_tracking=\%7B\%22tn\%22\%3A\%22R0\%22\%7D

Reis, D. R. M. (2014, August 26). Comment [Silva's Facebook page]. Retrieved from https://www.facebook.com/marinasilva. oficial/photos/a.144793905532248.25658. 126351747376464/848064325205199/?type $=3 \&$ comment_id $=848068091871489 \&$ offset $=0 \&$ total_comments=922\&comment tracking=\%7B\%22tn\%22\%3A\%22R9\% $22 \% 7 \mathrm{D}$

Rodrigues, A., \& Braga, A. (2014). Discourse analysis and ethnomethodological discourse analysis. Anais Do Encontro Anual Da Compós, 23, 1-19.

Rodrigues, R. M. (2014, October 17). Comment [Rousseff's Facebook page]. Retrieved from https://www. facebook.com/SiteDilmaRousseff/ videos/772541039466156/?comment_ id $=772614492792144$ \&offset=0\&total comments $=14894 \&$ comment_tracking=\%7B $\% 22$ tn $\% 22 \% 3 \mathrm{~A} \% 22 \mathrm{R} \% 22 \% 7 \mathrm{D}$

Sscpam, T. (2014, October 4). Comment [Silva's Facebook page]. Retrieved from https://www.facebook.com/marinasilva. oficial/photos/a.144793905532248.25658. $126351747376464 / 873180889360209 /$ ? type $=1 \&$ comment_id $=873191886025776$ \&reply_comment_id=873503532661278 \&total_comments=41\&comment_tracking $=\% 7 \mathrm{~B} \% 22 \operatorname{tn} \% 22 \% 3 \mathrm{~A} \% 22 \mathrm{R} 9 \% 22 \% 7 \mathrm{D}$
Schelb, C. G. (2014, October 16). Comment [Neves' Facebook page]. Retrieved from https://www.facebook.com/AecioNevesOficial/videos/862238933820989/?comment_id=862259797152236\&reply_ comment_id=862342360477313\&total_comments=255\&comment_tracking $=\% 7 \mathrm{~B} \% 22 \operatorname{tn} \% 22 \% 3 \mathrm{~A} \% 22 \mathrm{R} 9 \% 22 \% 7 \mathrm{D}$

Schopenhauer, A. (2009). The art of always being right. London, UK: Gibson Square Books.

Segaard, S. B., \& Nielsen, J. A. (2013). Local election blogs: Networking among the political elite. Information Polity, 18(4), 299-313. https://doi.org/10.3233/IP-130314

Silva, M. (2014, October 3). Comment [Silva's Facebook page]. Retrieved from https://www.facebook.com/marinasilva. oficial/photos/a.144793905532248.25658. 126351747376464/873180889360209/? type $=1 \&$ comment_id $=873191886025776$ \&offset=0\&total_comments $=646 \&$ com ment_tracking=\%7B\%22tn\%22\%3 A\%22R $\% 22 \% 7 \mathrm{D}$

Slimovich, A. (2012). Los Comentaristas Políticos em Facebook [Political commentators on Facebook] In Universidad Nacional de La Plata (Ed.), Conference Proceedings of Congreso de Periodismo y Medios de Comunicación (pp. 1-16). La Plata: FPyCS/UNLP. Retrieved from https://perio.unlp.edu.ar/ congresos/sites/perio.unlp.edu.ar.congresos/files/mesa_3-slimovich_final.pdf

Sørensen, M. P. (2016). Political conversations on Facebook - The participation of politicians and citizens. Media, Culture \& Society, 38(5), 664-685. https://doi. org/10.1177/0163443715620924

Souza, R. (2014, September 15). Comment [Silva's Facebook page]. Retrieved from https://www.facebook.com/marina silva.oficial/photos/a.858492327495732. $1073741870.126351747376464 / 8585$ $95390818759 /$ ?type $=3 \&$ comment_ id=85945359 $4066272 \&$ offset $=0 \&$ total comments $=207 \&$ comment_tracking $=\% 7 \mathrm{~B}$ \%22tn\%22\%3A\%22R3\%22\%7D

Stier, S., Bleier, A., Lietz, H., \& Strohmaier, M. (2018). Election campaigning on social media: Politicians, audiences, and the mediation of political communication on Facebook and Twitter. Political Communi- 
cation, 35(1), 50-74. https://doi.org/10.108 $0 / 10584609.2017 .1334728$

Stromer-Galley, J. (2000). On-Line interaction and why candidates avoid it. Journal of Communication, 50(4), 111-132. https:// doi.org/10.1111/j.1460-2466.2000. tb02865.x

Stromer-Galley, J., \& Wichowski, A. (2011). Political discussion online. In M. Consalvo \& C. Ess (Eds.), The Handbook of Internet Studies (pp. 168-187). Hoboken, NJ: Wiley. https://doi. org/10.1002/9781444314861.ch8

Sweetser, K. D., \& Weaver Lariscy, R. (2008). Candidates make good friends: An analysis of candidates' uses of Facebook. International Journal of Strategic Communication, 2(3), 175-198. https://doi. org/10.1080/15531180802178687

Torres, F. A. (2014, October 3). Comment [Silva's Facebook page]. Retrieved from https:// www.facebook.com/marinasilva.oficial/ photos/a.144793905532248.25658. 1263 $51747376464 / 873180889360209 /$ type $=$ $1 \&$ comment_id=873191886025776 \&offset=0\&total_comments $=646 \&$ comment tracking=\%7B $\% 22 \mathrm{tn} \% 22 \% 3 \mathrm{~A} \% 22 \mathrm{R} \%$ $22 \% 7 \mathrm{D}$
Tromble, R. (2018). Thanks for (actually) responding! How citizen demand shapes politicians' interactive practices on Twitter. New Media \& Society, 20(2), 676-697. https://doi. org/10.1177/1461444816669158

van Deth, J. W. (2014). A conceptual map of political participation. Acta Politica. International Journal of Political Science, 49(3), 349-367. https://doi.org/10.1057/ ap. 2014.6

van Dijck, J. (2012). Facebook as a tool for producing sociality and connectivity. Television \& New Media, 13(2), 160-176. https:// doi.org/10.1177/1527476411415291

Vitak, J., Zube, P., Smock, A., Carr, C. T., Ellison, N., \& Lampe, C. (2011). It's complicated: Facebook users' political participation in the 2008 election. CyberPsychology, Behavior, and Social Networking, 14(3), 107-114. https://doi.org/10.1089/cyber.2009.0226

Zerback, T., \&Wirz, D. S. (2021). Appraisal patterns as predictors of emotional expressions and shares on political social networking sites. Studies in Communication Sciences (SComS), 21(1), 27-45. https:// doi.org/10.24434/j.scoms.2021.01.003 